\title{
Gender stereotypes among road users
}

\author{
Alexander I. Dontsov ${ }^{a}$, Alexandra I. Kabalevskaya ${ }^{b}$ \\ ${ }^{a}$ Lomonosov Moscow State University, Moscow, Russia \\ ${ }^{b}$ Moscow State Pedagogical University, Moscow, Russia
}

\begin{abstract}
This article analyzes the mechanism of stereotyping as exemplified by gender stereotypes of road users. Gender stereotypes are not only viewed as an a priori image of a percept, but also examined 'in action' - at the very moment of their actualization with road users. In the paper we have identified the content of road users' gender stereotypes; analyzed the behaviour of male and female drivers, pinpointing a number of gender-specific behavioural features; demonstrated that male and female driving differ from each other in terms of speed, intensity and roughness; and identified the conditions and mechanisms underlying the actualization of gender stereotypes. Based on video and audio materials, we have found that drivers' gender-specific behavioural features are perceivable to road users: such features trigger the actualization of gender stereotypes as attributive schemes, which determine the interaction between road users, while also laying the foundation for gender stereotypes.
\end{abstract}

Key words: Gender stereotype, stereotyping, gender behaviour, road behaviour.

In modern social psychology, the study of determinants of social cognition suggests research into the social psychological mechanisms affecting the way an actor builds a consistent orderly image of the world. Researchers examine the mechanisms involved in the cognition and conception of social reality by an individual, and in reality's representation as his/her internal picture of the world, which necessitates the study of the social context making for the supra-individual character of social cognition and its attributes. The related problem of social stereotypes and stereotyping is core to the study of how the image of the interaction partner is formed.

Traditionally, social stereotypes, including gender ones, are approached as a priori images the individual creates in the process of his/her socialization, and invokes when evaluating people (Dontsov, Stefanenko, 2008). Social stereotypes result from the categorization of social experience conditioned by culture and upbringing. Social stereotypes reflect the typification of habitual estimates, expectations, viewpoints and prejudices. Such concepts of social bonds and relations are formed within a single culture and are stably shared by its members. They help maintain socially acceptable models of behaviour and the system's overall functio- 
ning. Stereotypes also satisfy individuals' intersubjective need for 'rock-solid values' and for standards of 'proper' social behaviour. As a factor in social relations, they provide consolidation not only of groups (gender or other), but of society in general (Dontsov, Emelyanova, 1987).

On the other hand, the mechanism of stereotyping manifests itself as part of the social perception process in human interaction (Kabalevskaya, 2012). The need for 'social knowledge' contained in stereotypes is conditioned by the need to promptly and socially accurately perceive and conceive reality. The schematic image of the percept acquires an applied aspect: it serves as a supply of 'ready-made knowledge' sparing the individual's efforts. Such knowledge covers acceptable behaviour, as well as motivational and role expectancies. It underlies the subject's interpretation of reality: the individual attributes his or her own expectations to the other, and sees the other's behaviour against this framework. Also, the individual seeks to pattern his/her behaviour following culturally determined expectations reflected in the stereotype. All this suggests that stereotypes should, first and foremost, be studied a priori with respect to the subject. In the current tradition of their empirical study, stereotypes are largely viewed as a result of stereotyping, i.e. retrospectively, and analyzed as socially typing categorical schemes. Analyzing such stereotyped knowledge, researchers tend to focus on its development process and content as reflecting the existing social discourse. But stereotyping would be also interesting to investigate from another angle, i.e. the application of stereotyped knowledge and its use in evaluating people. In other words, since individuals' interaction and mutual perception are mediated and regulated by internal constructs ('social stereotypes'), we need look at how these constructs are actualized, and at the causes and conditions of stereotype formation by an individual. However, the problem of stereotype actualization in people's behaviour and activity has only recently entered the scientific agenda and so far not been given proper consideration, although it is clearly a promising area for social psychology.

Traditional studies of social stereotypes (including gender) as historically evolved patterns of collective consciousness do not reveal the actual mechanisms of perception triggering the stereotyping process which is objectively (and perceptibly) caused by subjects' activity. To reveal these mechanisms, we need to explore the actual interaction between subjects and objects, particularly aspects of interaction providing for the appearance and actualization of gender stereotypes. This problem has been approached through the study of road users' gender stereotypes.

The research we are going to describe, on the one hand, follows the tradition studying gender stereotypes as categorical schemes within the subject's social conceptual system and, on the other hand, attempts to correlate gender stereotypes with the behavioural features invoking gender images in drivers' minds. The research had three key objectives. Firstly, we intended to identify and analyze the content of male and female drivers' gender images as formed within the cultural discourse and fixed in the individual consciousness, while also maintain and selfreplicated in drivers' road behaviour. The second objective was to examine driving activity and single out its gender-specific characteristics. Finally, we intended to investigate how road users perceive drivers' actual behaviour, and to identify the determinants responsible for the categorization of an observed driver and his/her activity as representing the respective gender group. What is intended, in fact, is to 
identify the moment of a gender stereotype manifestation during the interaction between road users.

The empirical research comprised two steps. The first, traditional part of the research addressed the content of road users' gender stereotypes. We studied websites, conducted survey polls on various automobile forums, organized focus groups, and made a series of interviews, applying content analysis to the data received. Overall, the research covered 142 road users. Respondents in the first part fell into the following categories: motor car drivers - 20 men and 20 women, aged from 19 to 56, with various levels of driving experience including six professional drivers (two men and four women); and indirect road users: 18 traffic police officers (men) with over 5 years of work experience, and 7 pedestrians (three men and four women), aged from 35 to 50, with no driving skills. Professional, social and economic or ethnic characteristics were not taken into account. The research also used forum replies by male and female drivers in the specifically provoked discussions of male/ female drivers' typical characteristics, their behaviour in various traffic situations, and their self-image as drivers. The sampling covered ten automobile forums, about 30 messages from each, posted by men and women over a certain time period. In total, we analyzed 185 messages by male drivers and 185 messages by female drivers, discussing their ideas about other male and female drivers, as well as about themselves. We calculated the average frequency with which characteristics were mentioned among men and women. A characteristic was added to the stereotype list if it was mentioned by no less than $25 \%$ of respondents.

The survey research also included a series of 40 semi-structured, in-depth interviews with male and female drivers, both amateur and professional. Drivers were equated in terms of experience and age and sorted into three small groups. The interview guide included questions relating to drivers' characteristic behaviour and interaction, and analysis of accident situations involving respondents, along with a number of projective questions on the characteristic of a 'natural-born driver', wishes concerning drivers, and evaluation of various traffic situations. Interview results were interpreted qualitatively.

The results of the first part were supplemented with the data received from two focus groups with a specifically designed topic guide. The participants were traffic police officers and pedestrians, asked about their views on road users, their characteristic behaviour and interaction in cases of offence, traffic accidents, and traffic safety from the gender viewpoint. The results were processed using content analysis.

The stereotypical image of a female driver includes a number of features named by drivers as well by traffic police officers and pedestrians. They perceive the female driver as incompetent in driving, lacking self-confidence, hesitant, unpredictable, egocentric and unsuccessful. Men intensify the negative aspect of the image, adding such negative features as inaptitude for driving, low intellectual level, and patterned mindset. Overall, respondents point to the secondary role of female drivers as road users and to their insufficient driving skills compared to male drivers. The stereotypical image of a male driver, on the contrary, is a model driver serving as a benchmark in any traffic situation. It includes such features as self-confidence and pragmatic character. But it is also characterized by impulsivity, nervousness, nonobservance of traffic rules, etc. Many of its features are negative and could hardly be deemed normative from the viewpoint of safety, which is the key traffic criterion. The stereotypical image of a male driver is also shared by various categories of road 
user and underlies the drivers' self-stereotyping — both, male and female, as follows from Charts 1 and 2.

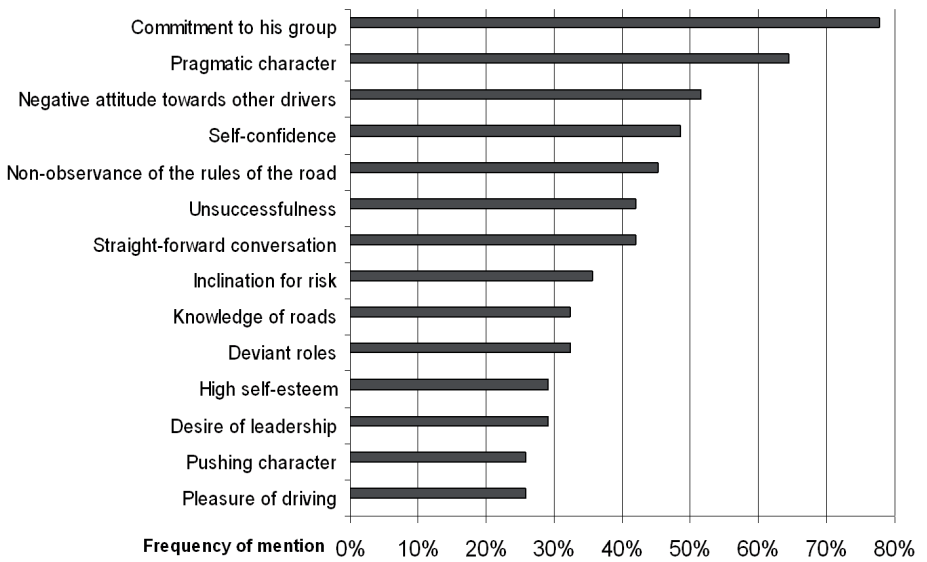

Chart 1. Self-Stereotype of Male Drivers

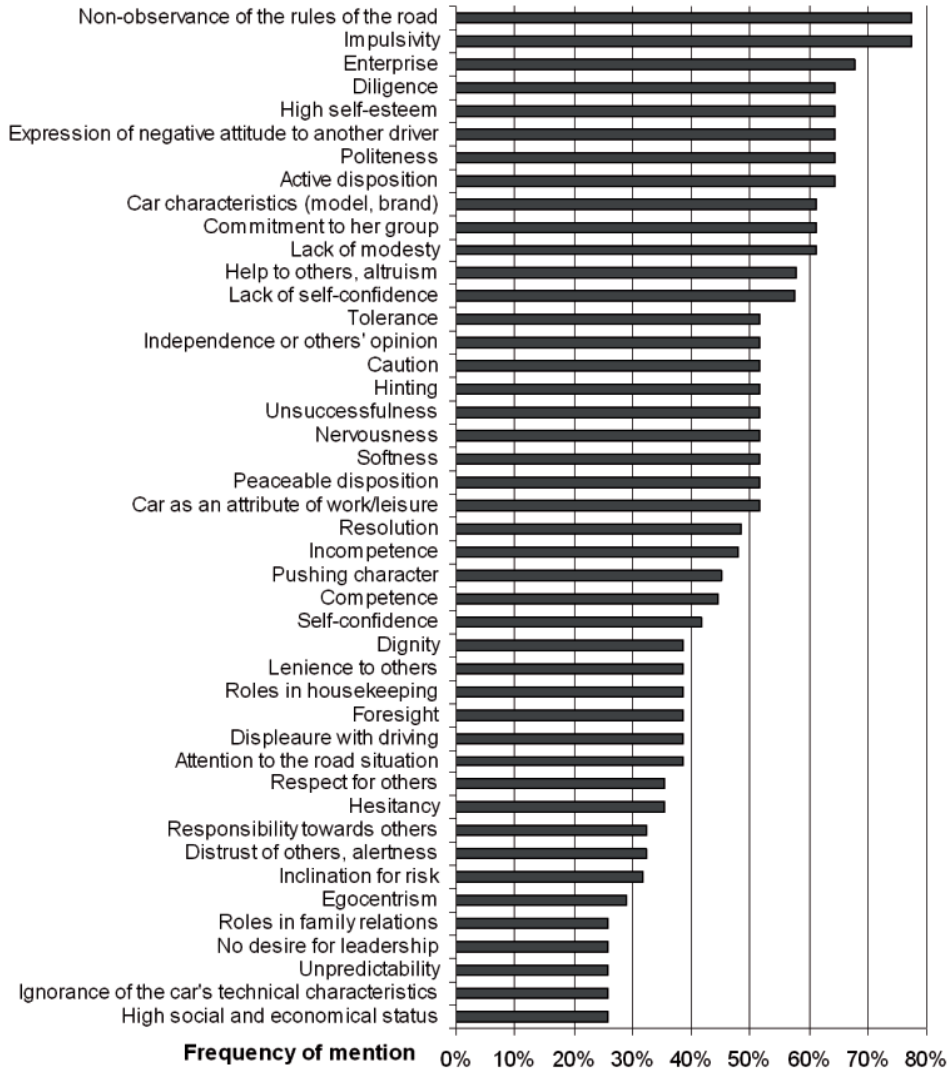

Chart 2. Self-Stereotype of Female Drivers 
Characteristics found in the self-stereotype of male drivers largely conform with their stereotype. In addition, male drivers emphasize their pleasure from driving and often appeal to deviant roles, thus signaling that such behaviour is acceptable in a traffic situation. The female drivers' self-stereotype also correlates closely with the male drivers' image but has certain specifics in its formation (Table 1): thus, features named by women themselves are partly adopted from the male image, either directly (for instance, nervousness, impulsivity, non-observance of rules) or with the opposite sign (for example, women tag themselves as polite and tolerant in contrast to the alleged impoliteness and intolerance of men). Interestingly, female drivers fully share the idea of their own incompetence. Their self-stereotype includes hesitance, incompetence, and lack of selfconfidence. Given such a combination of two self-images of female drivers, we might speak of a dual, positive-negative character of their self-stereotype. As the analysis of the interviews has shown, in case of success the positive features of the self-stereotype are actualized. Unlucky situations are explained by appealing to negative features. In-depth interviews with four professional female drivers also reveal the duality of their self-stereotype. Besides, female taxi drivers,

Table 1. Structure Specifics of Female Drivers' Self-Stereotype

\begin{tabular}{|c|c|}
\hline $\begin{array}{l}\text { Structure specifics of female drivers' } \\
\text { self-stereotype }\end{array}$ & Sample features \\
\hline Contrasting the male driver stereotype & $\begin{array}{l}\text { Respect for others } \\
\text { Leniency to others } \\
\text { Tolerance } \\
\text { Politeness, softness } \\
\text { Hinting } \\
\text { No desire for leadership } \\
\text { Displeasure from driving }\end{array}$ \\
\hline Resembling the male driver stereotype & $\begin{array}{l}\text { Non-observance of the rules of the road } \\
\text { Pushing character } \\
\text { Nervousness } \\
\text { Impulsivity } \\
\text { Self-confidence } \\
\text { Active disposition } \\
\text { Foresight } \\
\text { Enterprise } \\
\text { Lack of modesty } \\
\text { Competence } \\
\text { Resolution }\end{array}$ \\
\hline Resembling the female driver stereotype & $\begin{array}{l}\text { Unpredictability } \\
\text { Roles in family relations } \\
\text { Egocentrism } \\
\text { Hesitancy } \\
\text { Incompetence } \\
\text { Lack of self-confidence } \\
\text { Ignorance of the car's technical characteristics } \\
\text { Roles in housekeeping }\end{array}$ \\
\hline
\end{tabular}


just like non-professional female drivers, compared themselves to male drivers. However, they denied the gender specificity of this image: the meaning-making foundation of their activity was seen in the professional role of the driver. Female drivers' self-stereotype allows them to maintain a positive self-image and high self-esteem, to approvingly evaluate their behaviour and, on the whole, to raise the status of their group representatives.

In-depth interviews with male and female drivers with various driving experience also reveal the dynamics of motivational grounds in driving (Table 2). As driving experience grows, the dominant motives of road behaviour change: with female drivers, the motives of gaining self-confidence and of their own safety give way to the safety of others, while male drivers become less preoccupied with personal achievements (success and status), also for the sake of others - starting to view safe and accident-free driving also as an achievement.

Table 2. Dynamics of Driving's Motivational Grounds

\begin{tabular}{|c|c|c|}
\hline \multirow{2}{*}{ Driving experience, age } & \multicolumn{2}{|c|}{ Dominant motives of road behaviour } \\
\hline & Male drivers & Female drivers \\
\hline $\begin{array}{l}\text { Beginners } \\
\text { Driving experience: } 0-2 \text { years } \\
\text { Age: } 19-23 \text { years }\end{array}$ & $\begin{array}{l}\text { - Self-fulfillment (self-efficacy) } \\
\text { and attainment of material } \\
\text { welfare; }\end{array}$ & $\begin{array}{l}\text { - Safety (their own); } \\
\text { - Overcoming a lack } \\
\text { of self-confidence }\end{array}$ \\
\hline $\begin{array}{l}\text { Middle category } \\
\text { Driving experience: } 3-10 \text { years } \\
\text { Age: } 23-29 \text { years }\end{array}$ & $\begin{array}{l}\text { - Acknowledgement of profes- } \\
\text { sional success as a driver }\end{array}$ & \\
\hline $\begin{array}{l}\text { Experienced drivers } \\
\text { Driving experience: over } 10 \text { years } \\
\text { Age: } 35-56 \text { years }\end{array}$ & $\begin{array}{l}\text { - Care for personal accomplish- } \\
\text { ments (success, status) gives } \\
\text { place to care for others: safe, } \\
\text { accident-free driving as an } \\
\text { accomplishment }\end{array}$ & $\begin{array}{l}\text { - Motive of personal } \\
\text { safety comes to be } \\
\text { scaled against the } \\
\text { safety of others }\end{array}$ \\
\hline
\end{tabular}

And yet, summing up the results of the first part of the research, we may conclude that the Russian driving community is dominated by traditional patriarchal gender stereotypes. Such concepts reflect the gender asymmetry in this social sphere: they assign a normative benchmark to the male driver's image, whereas women act as secondary and incompetent road users.

The second part of the research examined gender stereotypes in correlation with the behaviour specifics of road users, and addressed the mechanism of their actualization in the real activity of representatives of the gender subgroups. The study of stereotyping as a mechanism of gender stereotype actualization at the moment of observing real gender-specific behaviour required a respective organization of the research scheme. First, we had to analyze men's and women's objective driving activity. Second, we needed to examine how road users perceive drivers' behaviour, i.e. to compare the perceived activity and its evaluation by observers. For this purpose, we made a video recording of the real behaviour of six male and six female drivers, including both beginners and experienced ones. The participants were four men and women, aged 21-26, with driving experience 
of less than two years, and eight men and women, aged 30-45, with driving experience of over 10 years. Each driver took the same car and made the same route containing areas of different characters and difficulty. The traffic was uniform because of the timing: the experiment was carried out between noon and 1:00 P.M. on working days. The drivers' activity during the trip was registered by three cameras (Table 3).

Table 3. Study of Drivers' Gender Behaviour

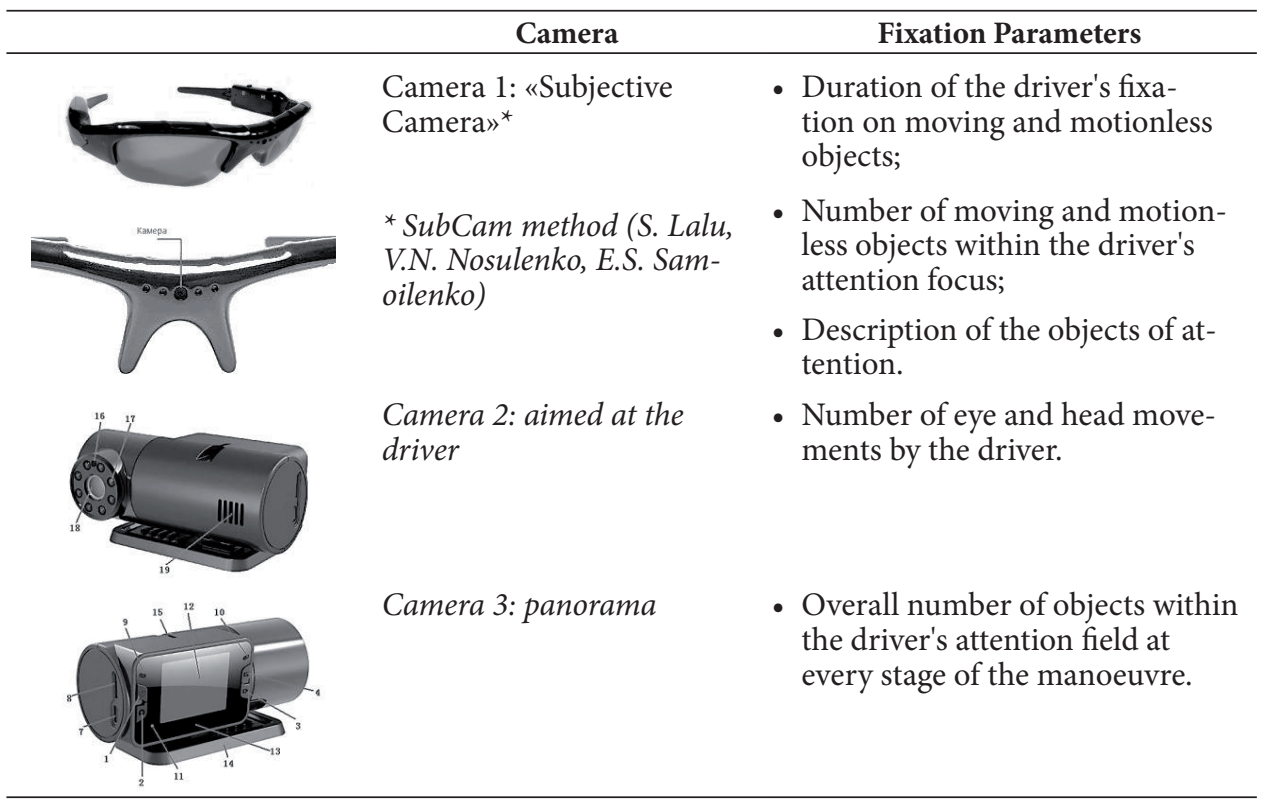

The first camera, nicknamed «subjective» in a number of publications, was located in the frame of a pair of glasses put on by the driver himself/herself, as a sort of a 'third eye'. It constantly recorded the driver's stare direction and attention focus. Two others were standard dashboard cameras. One was fixed on the windscreen of the car, directed at the driver and capturing his head and eye movements. Another, an all-sky camera, captured the overall quantity of objects within the driver's attention field. All drivers wore thick gloves, thus making their gender non-conspicuous on the recording.

The recordings showed that male and female driving styles were indeed different from each other. This is especially the case in complicated manoeuvres. A recording fragment with an uncontrolled $\mathrm{T}$ intersection became a matter of detailed analysis. Structural analysis of the driving activity (Kabalevskaya, 2012) was based on the data from all three cameras, and suggested a step-by-step analysis of the driver's actions during the manoeuvre, also taking the context into account. We analyzed objects within drivers' attention field, and calculated the average time of fixation upon them, which allowed us, in addition to the quantitative analysis, to reveal a number of qualitative gender-specific characteristics.

As a result of the analysis, we have identified a variety of gender-specific features related to driving activity and distribution of attention. 
Table 4. Manoeuvre Duration for Men and Women by Stages

\begin{tabular}{cccc}
\hline \multirow{2}{*}{ Group / sex } & \multicolumn{3}{c}{ Overall duration of the manoeuvre by stages } \\
& Preparatory stage & Main stage & Completion stage \\
\hline Male drivers & 15.03 & 3.7 & 4.8 \\
Female drivers & 49.5 & 3.8 & 2.5 \\
\hline
\end{tabular}

Note. ${ }^{\star}$ average duration of manoeuvre stages by subgroups.

Table 5. Description of the Objects of Attention of Male/Female Drivers by Stages

\begin{tabular}{|c|c|c|}
\hline $\begin{array}{l}\text { Group / } \\
\text { sex }\end{array}$ & Male drivers - (number of people) & Female drivers - (number of people) \\
\hline 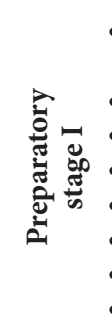 & $\begin{array}{l}\text { - vehicles moving in own and opposite } \\
\text { lanes }-6 \\
\text { - traffic lights }-5 \\
\text { - vehicles waiting to make a turn }-4 \\
\text { - control of side mirrors }-4 \\
\text { - control of own and opposite lanes }-3 \\
\text { - control of rear-view mirror }-2 \\
\text { - attention towards the road (straight) }-2 \\
\text { - car dashboard }-1\end{array}$ & $\begin{array}{l}\text { - traffic lights }-6 \\
\text { - control of own and opposite lanes }-4 \\
\text { - vehicles moving in own and opposite } \\
\text { lanes }-4 \\
\text { - vehicles waiting to make a turn }-4 \\
\text { - pedestrian }-4 \\
\text { - control of side mirrors }-3 \\
\text { - a bus on the right }-1 \\
\text { - car dashboard - } 1\end{array}$ \\
\hline 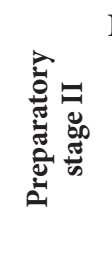 & Not detected. & $\begin{array}{l}\text { - repeated control of traffic lights- } 5 \\
\text { - vehicles moving in own and opposite } \\
\text { lanes }-3 \\
\text { - control of rear-view and side mir- } \\
\text { rors }-2 \\
\text { - control of own and opposite lanes }-1 \\
\text { - attention towards route map }-1\end{array}$ \\
\hline 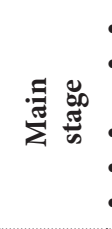 & $\begin{array}{l}\text { - control of left side mirrors }-2 \\
\text { - vehicles moving in own and opposite } \\
\text { lanes }-1 \\
\text { - attention towards the road (straight) }-1 \\
\text { - vehicles in opposite lane }-1 \\
\text { - control of opposite lane }-1\end{array}$ & $\begin{array}{l}\text { - control of traffic in own lane (turning } \\
\text { head to the right)- } 3 \\
\text { - control of traffic in the opposite lane at } \\
\text { the moment of the manoeuvre perfor- } \\
\text { mance (including a vehicle moving in } \\
\text { the opposite direction) - }-3\end{array}$ \\
\hline 造 & $\begin{array}{l}\text { - control of side mirrors }-5 \\
\text { - attention towards the road (straight) }-2 \\
\text { - control of rear-view mirror }-2 \\
\text { - one's own lane }-2 \\
\text { - glance 'elsewhere' (beyond the road) }-2 \\
\text { - control of opposite lane }-1 \\
\text { - vehicles moving in front of the driver }-1 \\
\text { - traffic lights }-1 \\
\text { - control of vehicles in opposite lane }-1 \\
\text { - } \text { attention towards route map }-1\end{array}$ & $\begin{array}{l}\text { - vehicle moving in front of the } \\
\text { driver }-4 \\
\text { - vehicles moving in opposite lane }-3 \\
\text { - control of left side mirror }-2 \\
\text { - glance at the traffic lights }-1 \\
\text { - attention towards the route map } \\
\text { and towards the car's interior ('else- } \\
\text { where') }-1\end{array}$ \\
\hline
\end{tabular}

Thus, female drivers spend almost three times as much time as men on a manoeuvre (Table 4). The average manoeuvre duration reached 57.5 seconds with women, while this figure was only 24.2 seconds for men. This fact is due to differences in distribution of attention (Table 5). Before the manoeuvre, at the preparatory stage consisting of observation and analysis of the road situation in order to 
decide on the action, female drivers consider both, main and secondary variables. The women's attention is divided between the traffic lights, their own and opposite lanes, and vehicles - moving and waiting to make a turn. In addition, four women out of six also monitored pedestrians and other objects beyond the relevant road situation. They give almost 1.5 times more attention to motionless objects than male drivers (Table 6). This ultimately produces an additional preparatory stage with female drivers, where they focus attention on the key objects - approaching obstacles. Male drivers have only one preparatory stage, as they initially focus on the main item. Men's attention is basically focused on vehicles in their own and opposite lanes, moving or waiting to make a turn, which are objectively the most significant obstacles to the intended manoeuvre.

Table 6. Time of Male/Female Drivers' Attention Fixation by Stages

\begin{tabular}{llcc}
\hline Stage & Driver's sex & $\begin{array}{c}\text { Ratio of fixation on } \\
\text { moving objects to the } \\
\text { number of moving } \\
\text { objects within the } \\
\text { attention focus }\end{array}$ & $\begin{array}{c}\text { Ratio of fixation on } \\
\text { motionless objects to the } \\
\text { number of motionless } \\
\text { objects within the } \\
\text { attention focus }\end{array}$ \\
\hline Preparatory stage (I) & Male drivers & 1.34 & 0.93 \\
& Female drivers & 1.29 & 1.39 \\
\hline Performance stage (II) & $\begin{array}{l}\text { Male drivers } \\
\text { Female drivers }\end{array}$ & 1.7 & - \\
\hline \multirow{2}{*}{ Completion stage (III) } & Male drivers & 0.5 & - \\
& Female drivers & 1 & 2.75 (data for \\
& & 0.67 & two drivers) \\
\hline
\end{tabular}

During the manoeuvre itself, men and women did not display considerable differences. At this stage the driver checks his/her anticipations concerning the road situation dynamics against its real progress. The manoeuvre took 3.7 and 3.8 seconds with male and female drivers. respectively.

The stage of the manoeuvre's completion revealed certain qualitative differences. Women checked the success and safety of the completed manoeuvre twice as fast as men -2.5 seconds against 4.8 seconds, respectively. However, control of the rear-view and side mirrors helps male drivers orient themselves and, accordingly, spend less time afterwards in the preparatory stage of a new manoeuvre. Female drivers' attention (drawn by the route map, for example, and by the car's interior) is distributed not in accordance with the objectives of either control or adaptation. As a result, female drivers have to spend more time preparing for the next manoeuvre and to extend its preparatory stage.

Thus, the analysis has demonstrated that driving activity is indeed gender-specific and revealed a number of characteristic male/female driver features. These features are also found in the content of the gender stereotypes identified above: hesitancy and unpredictability in the female drivers' image vs. a pushy character and impulsivity in the male drivers' stereotype. These results have enabled a supposition that the stereotypes we have identified reflect drivers' actual gender-specific features. Proceeding from this, we have formulated the main hypothesis of 
the present research: the mechanism of gender stereotyping is based on road users' perception of objective gender-specific features of drivers' behaviour, as reflected in verbal gender-related evaluations, which results in a categorization of the percept as a representative of the respective gender subgroup, with the subsequent attribution of the gender stereotype content to the percept.

In order to verify these suppositions, we needed to detect, firstly, whether drivers' gender-specific behavioural features were perceivable to other road users and, secondly, to what extent perception of these features actualized the gender stereotypes.

For this purpose, we selected five recordings with most conspicuous samples of gender-specific behaviour. Recordings featuring two female and three male drivers with the driving experience from less than two years to over ten years, were randomly shown to various road users: 34 male drivers and 31 female drivers with various driving experience who had not been involved in the first part of the research, as well as to 10 traffic police officers and 7 pedestrians. The respondents were asked to characterize the driver they observed on the recording. The interviews did not specifically draw respondents' attention to gender issues. As we have mentioned above, the driver's sex was not obvious due to the gloves.

The results are as follows.

Table 7. Analysis of Respondents' Comments (based on 325 interviews)

\begin{tabular}{|c|c|c|}
\hline $\begin{array}{c}\text { Characteristics of drivers' } \\
\text { activity }\end{array}$ & $\begin{array}{l}\text { Attributed to a Male Driver } \\
\text { (sample comments) }\end{array}$ & $\begin{array}{l}\text { Attributed to a Female Driver } \\
\text { (sample comments) }\end{array}$ \\
\hline Driving speed & $\begin{array}{l}\text { «very fast, at full throttle, } \\
\text { high speed» }\end{array}$ & «goes quietly, without haste» \\
\hline \multirow[t]{2}{*}{ Driving roughness } & $\begin{array}{l}\text { «smoothly, without } \\
\text { accelerations» }\end{array}$ & «jerkily» \\
\hline & «not yanking, without fuss» & «yanking, fussing around» \\
\hline Driving intensity & $\begin{array}{l}\text { «changes lanes promptly } \\
\text { and confidently», } \\
\text { «manoeuvres quickly» }\end{array}$ & $\begin{array}{l}\text { «changes lanes slowly», } \\
\text { «can't pull out, brakes» }\end{array}$ \\
\hline Action length & - & $\begin{array}{l}\text { «just waiting there», } \\
\text { «staring too long» }\end{array}$ \\
\hline Violation of rules & $\begin{array}{l}\text { «ran a red light, got to the } \\
\text { oncoming lane, didn't let } \\
\text { the pedestrian cross» }\end{array}$ & - \\
\hline
\end{tabular}

We have applied content analysis to the respondents' comments (Table 7). As a result, $66 \%$ of comments on driving activity turned out to be gender-related. These comments addressed driving speed, roughness, intensity, and time and spatial characteristics. The characteristics were bi-polar and ascribed either to a male, or to a female driver. They corresponded to the gender-specific driving features identified earlier. Thus, as respondents' evaluative comments contained references to such features, the latter must be perceivable to various road users.

The next and final step in the research was to compare respondents' comments with the observed behaviour of drivers. A combined analysis of audio and video 
materials allowed the process of the respondent's perception and conception of a driver's activity to be reconstructed: an objective description of the driving activity, in comparison with the latter's verbal characteristics and attribution to a specific gender subject, allowed the respondent's attention focus to be identified. Thus we were able to watch the mechanism of stereotyping in action, at the very moment of gender stereotypes' appearance (Table 8).

Table 8. Combined Analysis of Audio and Video Materials

\begin{tabular}{|c|c|c|}
\hline $\begin{array}{l}\text { Driver's } \\
\text { actions }\end{array}$ & $\begin{array}{l}\text { - Moves as if to start the manoeuvre } \\
\text { but breaks off; } \\
\text { - Waits for something for a long } \\
\text { time; } \\
\text { - Slows down; } \\
\text { - Performs the manoeuvre too slowly } \\
\text { compared to other traffic members; } \\
\text { - Resumes the initial position after } \\
\text { evaluating his/her actions as wrong; } \\
\text { - Much viewing activity not accom- } \\
\text { panied by any actions related to the } \\
\text { manoeuvre. } \\
\text { DRIVER'S PASSIVE BEHAVIOUR }\end{array}$ & $\begin{array}{l}\text { - Performs the manoeuvre quickly and } \\
\text { without preliminary orientation; } \\
\text { - Crosses the intersection before other } \\
\text { traffic members; } \\
\text { - Accelerates the speed; } \\
\text { - Performs the manoeuvre at intensive } \\
\text { traffic and simultaneously observes } \\
\text { the traffic around; } \\
\text { - Much viewing activity accompanied } \\
\text { by the performance of the manoeuv- } \\
\text { re; } \\
\text { - Continues riding despite the red } \\
\text { light. } \\
\text { DRIVER'S ACTIVE BEHAVIOUR }\end{array}$ \\
\hline $\begin{array}{l}\text { Driver's } \\
\text { gender cat- } \\
\text { egorization }\end{array}$ & Attribution to a FEMALE DRIVER & Attribution to a MALE DRIVER \\
\hline \multicolumn{3}{|c|}{$\begin{array}{l}\text { Interpretation of the driver's behaviour: } \\
\text { attributive characteristics of gender behaviour (samples) }\end{array}$} \\
\hline $\begin{array}{l}\text { Drivers, } \\
\text { traffic police } \\
\text { officers, } \\
\text { pedestrians }\end{array}$ & $\begin{array}{l}\text { "Confidence is lacking. Waits too } \\
\text { long, there was a chance to cross, } \\
\text { plays safe, looks around often but is } \\
\text { not moving. A young girl who hasn't } \\
\text { driven much yet». }\end{array}$ & $\begin{array}{l}\text { "Very cheeky, expects to squeeze in but } \\
\text { nobody lets him - male behaviour»; } \\
\text { «Dashed from the lights - obviously } \\
\text { wanted to be first. The boy's a road } \\
\text { hog!». }\end{array}$ \\
\hline
\end{tabular}

Thus, a comparison of audio and video materials shows that respondents made gender-related remarks while observing drivers' most complicated manoeuvres. Drivers' passive behaviour was attributed to a female driver, whereas active behaviour was interpreted as male. Therefore, 'activity vs. passivity' as the universal binary opposition may be taken as an implicit condition and factor in the actualization of gender stereotypes with all road users. Slow and step-by-step manoeuvre performance by women, and its quick unbroken performance by men, are noticed by road users and become the foundation for the gender interpretation of behaviour (Table 9).

Thus, the results have generally confirmed the hypothesis of the research and allowed the following conclusions to be made:

1. Gender stereotypes of road users are an important determinant of social relations in the traffic community. They are actualized in complex, uncommon and challenging traffic situations. 
2. Gender stereotypes determine the process of road users' perception and interaction, even when the object's sex is unknown. In this case their actualization is triggered by the procedural characteristics of the drivers.

3. These characteristics are gender-specific and form the foundation of drivers' gender behaviour. The characteristics are perceivable to all road users who implicitly differentiate them applying the 'activity/passivity' criterion; are reflected in comments on driving activity; and are linked by the observers to the driver's sex without any other objective grounds for this.

4. Gender stereotypes of road users are a gender-based interpretation of the driving style, including normative ideas of men and women's psychological and behavioural features.

Table 9. 'Grain of Truth' within the Stereotype

\begin{tabular}{|c|c|c|c|}
\hline & $\begin{array}{l}\text { Drivers' Real } \\
\text { Behaviour }\end{array}$ & $\begin{array}{l}\text { Road Users' Comments } \\
\text { (samples) }\end{array}$ & $\begin{array}{c}\text { Gender Stereotype } \\
\text { Content }\end{array}$ \\
\hline \multirow[t]{5}{*}{$\begin{array}{l}\text { Female } \\
\text { drivers }\end{array}$} & $\begin{array}{l}\text { Performed the manoeuv- } \\
\text { re slowly }\end{array}$ & $\begin{array}{l}\text { "Stands still and waits to be let } \\
\text { through, or is afraid and plays } \\
\text { safe» }\end{array}$ & $\begin{array}{l}\text { Caution } \\
\text { Hesitancy }\end{array}$ \\
\hline & $\begin{array}{l}\text { Distributed attention } \\
\text { among various traffic } \\
\text { objects (including non- } \\
\text { relevant ones) }\end{array}$ & $\begin{array}{l}\text { «Turning her head but not } \\
\text { moving. Don't know what she's } \\
\text { doing» }\end{array}$ & $\begin{array}{l}\text { Patterned mindset } \\
\text { Foresight }\end{array}$ \\
\hline & $\begin{array}{l}\text { Took time to prepare } \\
\text { to the manoeuvre (two } \\
\text { stages) }\end{array}$ & $\begin{array}{l}\text { "Winking too long - you cannot } \\
\text { possibly guess when exactly she } \\
\text { will start off» }\end{array}$ & Unpredictability \\
\hline & $\begin{array}{l}\text { Didn't control the effi- } \\
\text { ciency and safety of the } \\
\text { completed manoeuvre }\end{array}$ & $\begin{array}{l}\text { «Never looked in the right mir- } \\
\text { ror while changing lanes }- \text { not } \\
\text { once!» }\end{array}$ & Egocentrism \\
\hline & $\begin{array}{l}\text { Got distracted (attention } \\
\text { elsewhere) }\end{array}$ & $\begin{array}{l}\text { "Drove up and stopped! Didn't } \\
\text { she have time to check the map } \\
\text { beforehand?". }\end{array}$ & Inclination for risk \\
\hline \multirow[t]{5}{*}{$\begin{array}{l}\text { Male } \\
\text { drivers }\end{array}$} & $\begin{array}{l}\text { Performed the manoeuv- } \\
\text { res quickly }\end{array}$ & $\begin{array}{l}\text { "Pressed the accelerator to be the } \\
\text { first to leave the right lane - as } \\
\text { if it was vital to dash rapidly» }\end{array}$ & $\begin{array}{l}\text { Desire for leadership, } \\
\text { Pushy character }\end{array}$ \\
\hline & $\begin{array}{l}\text { Distributed attention } \\
\text { among the most impor- } \\
\text { tant traffic objects }\end{array}$ & $\begin{array}{l}\text { "Didn't look at the sign or notice } \\
\text { the trolley bus. Didn't look and } \\
\text { just drove off» }\end{array}$ & $\begin{array}{l}\text { Attention / Lack of } \\
\text { attention to the road } \\
\text { situation }\end{array}$ \\
\hline & $\begin{array}{l}\text { Quick orientation in the } \\
\text { road situation }\end{array}$ & $\begin{array}{l}\text { "Oriented himself quickly, made } \\
\text { sure there were no obstacles and } \\
\text { drove off». }\end{array}$ & $\begin{array}{l}\text { Impulsivity, Active } \\
\text { disposition, Predicta- } \\
\text { bility for others }\end{array}$ \\
\hline & $\begin{array}{l}\text { Controlled the efficiency } \\
\text { and safety of a completed } \\
\text { manoeuvre }\end{array}$ & «Checks the road situation» & Pragmatic character \\
\hline & $\begin{array}{l}\text { Violated the rules of the } \\
\text { road (running a red light, } \\
\text { etc.) }\end{array}$ & $\begin{array}{l}\text { «0 km/h speed limit - who } \\
\text { cares! } 20 \mathrm{~km} / \mathrm{h} \text { speed limit - } \\
\text { even more so! By all means, } \\
\text { it's a man at the wheel. And he } \\
\text { went through two solid lines to } \\
\text { overtake!» }\end{array}$ & $\begin{array}{l}\text { Non-observance of } \\
\text { the rules of the road }\end{array}$ \\
\hline
\end{tabular}


5. The Russian traffic community is dominated by traditional gender stereotypes. The male driver image serves as a benchmark, whereas the female driver image is presented as a secondary and incompetent road user. Even though this view is shared by all members of the traffic community, female drivers included, the latter have a positive self-image allowing them to maintain a compensatory self-stereotype. Such gender stereotypes support the gender asymmetry in this social area becoming rooted in individual consciousness and self-replicating in drivers' road behaviour.

\section{Conclusion}

The present research offers a new angle on the study of social stereotypes. Its principal result is that stereotypes are no longer treated as a priori images with respect to male/female subjects. In other words, stereotyping as a social cognitive mechanism and the resulting gender stereotypes have for the first time been investigated, not just as an object's a priori image, categorized and conceived within a gender subgroup system, but also as attributes of interaction between the subject and the object of stereotyping. It was possible to abandon the apriority since the study focus was shifted from verbal clichés to their actualization in gender behaviour and the latter's individual analysis. This enabled us to identify the conditions and mechanisms of actualization of gender stereotypes among subjects interacting in a road traffic situation and to reveal the perception mechanisms triggering this process.

In reconstructing the process of actualization of gender stereotypes in perception of drivers' activity and behaviour, we came to single out the 'activity-passivity' characteristic as the underlying condition of the verbal clichés appearance. 'Gender knowledge' contained in the stereotypical image affected the perceptual process and conditioned the perception of behavioural features which subsequently allowed the attribution of a particular sex to the subject. Afterwards, the subject was ascribed all intentional characteristics of the gender subgroup and his/her behaviour was interpreted accordingly. The gender stereotype in this case acted rather like an attributive scheme determining individuals' interaction and mutual perception. Thus, in spotting the moment of actualization of gender-related remarks in comparison with the object's actual behaviour, we identified the very moment when road users felt the necessity to invoke gender clichés as a form of social knowledge which helps evaluate, understand and order the whole perceived context of road traffic - not as intact and safe, but rather as socially logical and predictable.

Besides, stretching in our analysis beyond the views of social reality and addressing the reality itself, we have managed to clarify the long-standing problem of the 'grain of truth' within the stereotypical ideas of various social objects and phenomena. It turned out that the content of the stereotype reflects actual features of the reality in question - in our case, of gender-specific driving behaviour. We may thus conclude that differences between gender subgroups are produced, along with the adopted gender role, by the objective gender-specific behaviour of male and female drivers. However, the quality of driving is emphasized in accordance with the gender asymmetry dominating the traffic community views, and gender stereotypes maintain the current gender inequality both in the individual consciousness 
and in the interaction between gender subgroups, implanting attributive schemes of interpretation corresponding to the socially formed gender expectancies.

Thus, with due acknowledgement of the cognitive paradigm and of the study of gender stereotypes in personal representation, this research abandons the retrospective approach to the study of stereotyping. Stereotyping is viewed in action, and gender stereotypes are analysed in the moment of their appearance as satisfying the need for socially stable and commonly shared ideas. The actualization of gender stereotypes may be triggered not only by the object of stereotyping, but also by its activity involving a number of gender-specific features which underlie gender behaviour. In the present research, perception of these features is universal to all road users and actualizes gender stereotypes as attributive schemes which determine road users' interaction.

Thus, the hypothesis put forward in the research has been confirmed, and the analysis results allow us to construe the mechanism of stereotyping as a form of social cognition of the world, and gender stereotypes - as attributive schemes of the world's description.

\section{References}

Dontsov, A.I., Stefanenko, T.G. (2008). Socialnie stereotipi: Vchera, segodny, zavtra [Social stereotypes: yesterday, today, tomorrow] In G.M. Andreeva, A.I. Dontsov (Ed.) Social'naja psihologija $v$ sovremennom obshhestve [Social psychology in the modern world]. Moscow: Aspekt Press.

Dontsov A.I., Emelyanova T. P. (1987). Koncepcia socialnih predstavleniy vo francyzskoy socialnoy psihologii [The concept of social representations in French social psychology]. Moscow: MSU.

Kabalevskaya, A.I. (2012). Predstavlenia o gendernih stereotipah v sovremennoy socialnoy psihologii [Ideas of gender stereotypes in modern social psychology] Psikhologicheskie Issledovaniya [Psychological Studies], 2 (22), p. 4. Retrieved from http://psystudy.ru

Kabalevskaya A.I. (2012). Sovremennie metodi issledovaniya voditelskoy deyatelnosti v transportnoy psihologii [Contemporary methods of drivers' activity research in transport psychology]. Rossiyskiy nauchniy jurnal [Russian Scientific Journal], 3(28), 211-216.

Received: 20 December 2012

Accepted: 12 February 2013

Available Online: 27 November 2013 